ARTICLE

Received 5 Feb 2015 | Accepted 17 Sep 2015 | Published 28 Oct 2015

DOI: $10.1038 /$ ncomms 9659

\title{
Early Pliocene onset of modern Nordic Seas circulation related to ocean gateway changes
}

\author{
Stijn De Schepper ${ }^{1,2}$, Michael Schreck ${ }^{3,4}$, Kristina Marie Beck ${ }^{2}$, Jens Matthiessen ${ }^{4}$, Kirsten Fahl ${ }^{4}$ \\ \& Gunn Mangerud ${ }^{2}$
}

The globally warm climate of the early Pliocene gradually cooled from 4 million years ago, synchronous with decreasing atmospheric $\mathrm{CO}_{2}$ concentrations. In contrast, palaeoceanographic records indicate that the Nordic Seas cooled during the earliest Pliocene, before global cooling. However, a lack of knowledge regarding the precise timing of Nordic Seas cooling has limited our understanding of the governing mechanisms. Here, using marine palynology, we show that cooling in the Nordic Seas was coincident with the first trans-Arctic migration of cool-water Pacific mollusks around 4.5 million years ago, and followed by the development of a modern-like Nordic Seas surface circulation. Nordic Seas cooling precedes global cooling by 500,000 years; as such, we propose that reconfiguration of the Bering Strait and Central American Seaway triggered the development of a modern circulation in the Nordic Seas, which is essential for North Atlantic Deep Water formation and a precursor for more widespread Greenland glaciation in the late Pliocene.

\footnotetext{
${ }^{1}$ Uni Research Climate, Bjerknes Centre for Climate Research, Allégaten 55, N-5007 Bergen, Norway. ${ }^{2}$ Department of Earth Science, University of Bergen Allégaten 41, N-5007 Bergen, Norway. ${ }^{3}$ Arctic Research Centre, Korea Polar Research Institute, 26 Songdomirae-ro, Yeonsu-gu, $406-840$ Incheon, Korea. ${ }^{4}$ Alfred Wegener Institute, Helmholtz Centre for Polar and Marine Research, Am Alten Hafen 26, 27568 Bremerhaven, Germany. Correspondence and requests for materials should be addressed to S.D.S. (email: stijn.deschepper@uni.no).
} 
$\mathrm{T}$ he early Pliocene (5-4 million years ago, Ma) is characterized by globally warmer sea surface temperatures and a reduced meridional temperature gradient compared with the present ${ }^{1-3}$ at atmospheric carbon dioxide concentrations of $\sim 400$ p.p.m. ${ }^{4}$. Following the 'early Pliocene climatic optimum' (4.4-4.0 Ma), atmospheric carbon dioxide concentrations decrease $^{4}$ and a cooling is observed in sea surface temperature records from around the globe ${ }^{2}$. Local cooling of the seas around Iceland occurred earlier in the early Pliocene, together with ${ }^{5}$ or even before $^{6}$ the first arrival of cool-water Pacific mollusks in Iceland. The arrival of cool-water Pacific mollusks ${ }^{7}$, which was recently re-dated to around $4.5 \mathrm{Ma}$ (ref. 8), has been linked to inflow of Pacific waters into the Nordic Seas via the Bering Strait ${ }^{7-9}$.

Today, water flows from the Pacific through the narrow and shallow $(\sim 50 \mathrm{~m})$ Bering Strait into the Arctic and North Atlantic, influencing meridional overturning circulation strength and global climate $^{10}$. The first inflow of Pacific water into the Arctic and Atlantic oceans has been determined based on the first occurrence of cool-water Pacific marine invertebrates (mollusks, gastropods) in 4.5-Myr-old sediments of the Tjörnes section in Iceland ${ }^{8,11}$. The implied northern migration pathway for these cool-water organisms is more plausible than a tropical pathway via the Central American Seaway. Although deep-water exchange across the Central American Seaway likely halted in the late Miocene ${ }^{12-14}$, a further shoaling phase in the early Pliocene has been interpreted between $\sim 4.8$ and $4.2 \mathrm{Ma}$ (refs 15,16). Proxy data and modelling experiments suggest that the shoaling led to increased North Atlantic meridional overturning circulation ${ }^{16}$, a Nordic Seas circulation with a stronger Norwegian Atlantic Current and a cooler and fresher East Greenland Current ${ }^{17}$, but also the onset of northward flow through the Bering Strait into the Arctic ${ }^{18,19}$.

As the connection between the North Atlantic and Arctic Ocean, and a region of North Atlantic Deep Water formation, the Nordic Seas are an integral part of the Atlantic meridional overturning circulation ${ }^{20}$. The modern Nordic Seas can be divided into a polar, Arctic and Atlantic domain ${ }^{21}$ based on different surface water masses and the position of the polar and Arctic front (Fig. 1). The strong east-west sea surface temperature and salinity gradient is caused by inflow of relatively warm saline Atlantic water in the southeast, continuing as the Norwegian Atlantic Current towards the Arctic Ocean, and by export of cool, fresher Arctic water via the East Greenland Current in the west ${ }^{22}$. This Nordic Seas circulation was hypothesized to be initiated in the early Pliocene as a consequence of Central American Seaway closure $^{17}$, but a precise timing, encompassing mechanism and conclusive data from the Nordic Seas remained elusive.

Here, using new marine palynological data (palynomorphs including dinoflagellate cysts and acritarchs) from Norwegian Sea Ocean Drilling Program (ODP) Hole 642B and an existing record from Iceland Sea ODP Hole 907A (ref. 23), we demonstrate that the Nordic Seas cooled and a zonal sea surface temperature gradient developed around $4.5 \mathrm{Ma}$, preceding the global climate cooling and atmospheric carbon dioxide decline from 4.0 Ma. We link this change in surface ocean conditions to inflow of fresher, cooler Pacific water via the Bering Strait into the Nordic Seas along the East Greenland Current pathway around 4.5 Ma.

\section{Results}

Marine palynology at Norwegian Sea ODP Hole 642B. In the early Pliocene, between 5.0 and $4.5 \mathrm{Ma}$, the palynological assemblages indicate an outer shelf environment influenced by warm, temperate waters. The dinoflagellate cyst assemblage contains the typical early Pliocene dinoflagellate cyst taxa Batiacasphaera micropapillata complex, Corrudinium devernaliae, Operculodinium tegillatum, Pyxidinopsis vesiculata and Reticulatosphaera actinocoronata (Fig. 2; Supplementary
Data 1). The dominant dinoflagellate cyst taxa B. micropapillata complex (3-43\%), Spiniferites/Achomosphaera spp. (5-42\%), Protoperidinioids (6-54\%) and occasionally Nematosphaeropsis labyrinthus (2-29\%) indicate an outer shelf, consistent with the location of ODP Hole 642B on the Vøring Plateau. The acritarch assemblage is dominated by Cymatiosphaera? invaginata, and occasionally by Lavradosphaera crista and Cyst type I of de Vernal and Mudie (1989). The high acritarch $(51,388 \pm 14,187$ acritarchs per g sediment) and dinoflagellate cyst $(32,993 \pm 9,140$ cysts per g sediment) concentrations, and the presence, but not dominance, of several oceanic genera (for example, Impagidinium, Invertocysta) are consistent with a nutrient-rich outer shelf environment. Both dinoflagellate cysts with a modern (sub)tropical distribution (for example, Melitasphaeridium choanophorum, Tuberculodinium vancampoae) and with a cool-water affinity (for example, Filisphaera filifera) occur in this interval. The high Warm/Cold index (W/C index, see Methods), due to the higher number of warm-water taxa (mainly Operculodinium israelianum, Operculodinium? eirikianum, O. tegillatum and M. choanophorum), indicates warm temperate conditions. A brief cooling can be interpreted from the W/C index around 4.9$4.8 \mathrm{Ma}$ (Fig. 3; Supplementary Data 1), due to an increase of the cool-water species $F$. filifera.

After $4.5 \mathrm{Ma}$, the palynological assemblages indicate an outer shelf environment influenced by cooler waters compared with the interval 5.0-4.5 Ma. The typical early Pliocene marker taxa B. micropapillata complex, C. devernaliae, O. tegillatum, $P$. vesiculata, $R$. actinocoronata and the acritarch Cyst type I of de Vernal and Mudie (1989) disappeared around 4.5 Ma (Fig. 2; Supplementary Data 1). The dominant taxa are cysts of Protoceratium reticulatum (5-45\%), Spiniferites/Achomosphaera spp. (14-23\%), N. labyrinthus (5-12\%) and F. filifera (0-13\%). The previously abundant Protoperidinioids decrease to less than $5 \%$ of the total assemblage, indicating reduced nutrient availability. Palynomorph concentrations drop considerably to $8,684 \pm 1,361$ dinoflagellate cysts per $\mathrm{g}$ sediment and $22,803 \pm 3,148$ acritarchs per g sediment. Such concentrations, the abundant Spiniferites/Achomosphaera spp. (14-21\%) and dominant cysts of $P$. reticulatum (29-45\%), which are known to be abundant around shelf edge environment ${ }^{24}$, are consistent with an outer shelf environment. The occurrence of several oceanic taxa (for example, Impagidinium) indicates influence of open-ocean waters. Cysts of $P$. reticulatum, an indicator for inflow of warm North Atlantic waters into the Pliocene Nordic Seas ${ }^{25,26}$, are present in the record since $4.5 \mathrm{Ma}$ and become dominant from 4.23 Ma. The (sub)tropical and thermophilic dinoflagellate cysts Lingulodinium machaerophorum, M. choanophorum, Dapsilidinium pseudocolligerum and O.? eirikianum further confirm that warm Atlantic water influenced the Norwegian Sea. However, increasing numbers of cool-water taxa F. filifera and Impagidinium pallidum and a decrease of warm-water taxa (for example, O? eirikianum, $O$. tegillatum and O. israelianum) results in a drop in the W/C index and thus a cooling relative to the period between 5.0 and $4.5 \mathrm{Ma}$.

Marine palynology at Iceland Sea ODP Hole 907A. In the early Pliocene between 5.0 and $4.5 \mathrm{Ma}$, the palynological assemblages indicate an open-ocean environment, with input from the shelf, influenced by temperate waters. Comparable to the Norwegian Sea, the same early Pliocene marker species such as O. tegillatum, O.? eirikianum, B. micropapillata complex and R. actinocoronata occur in ODP Hole 907A (Fig. 2; Supplementary Data 2). The dinoflagellate cyst assemblage is dominated by $N$. labyrinthus (0-65\%), and occasionally B. micropapillata complex (0-47\%), Spiniferites elongatus (1-50\%) and Spiniferites spp. (0-12\%). Protoperidinioids $(2-15 \%)$ are common to abundant throughout 

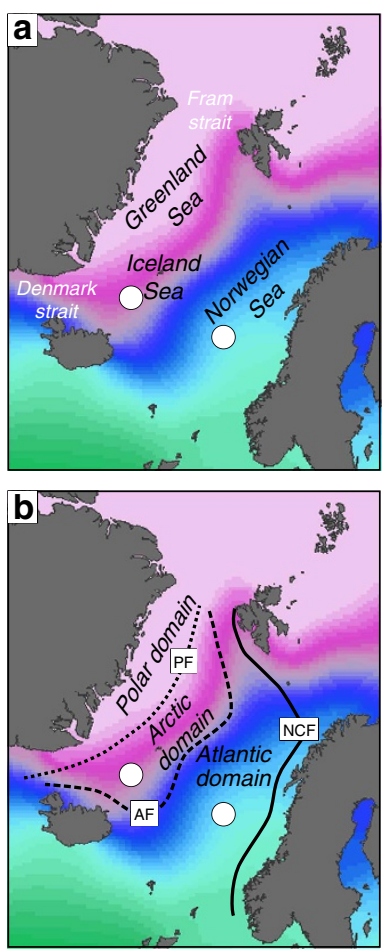

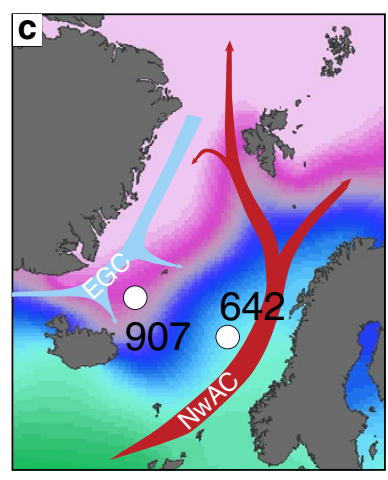

Study sites

ODP Hole 642B

$67^{\circ} 13.5^{\prime} \mathrm{N}, 2^{\circ} 55.7^{\prime} \mathrm{E}$

ODP Hole $907 \mathrm{~A}$

$69^{\circ} 15.0^{\prime} \mathrm{N}, 12^{\circ} 41.9^{\prime} \mathrm{W}$

Other discussed sites

DSDP Hole 610A

$53^{\circ} 13.30^{\prime} \mathrm{N}, 18^{\circ} 53.2^{\prime} \mathrm{W}$

DSDP Hole 603C

$35^{\circ} 29.78^{\prime} \mathrm{N}, 70^{\circ} 1.83^{\prime} \mathrm{W}$

ODP Hole 646B

$58^{\circ} 13^{\prime} \mathrm{N}, 48^{\circ} 22^{\prime} \mathrm{W}$

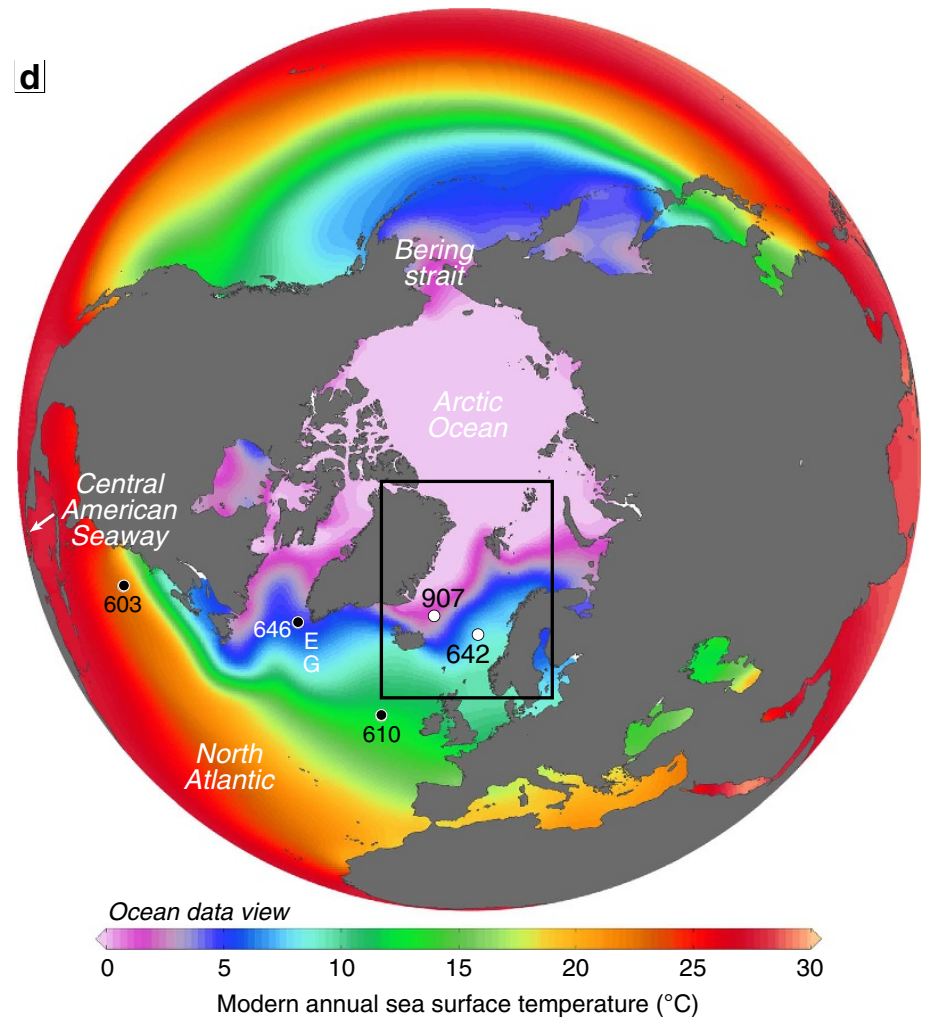

Figure 1 | Modern Nordic Seas oceanography. (a) The Nordic Seas encompass the Norwegian Sea, Iceland Sea and Greenland Sea. (b) The Nordic Seas divide into a polar, Arctic and Atlantic domain ${ }^{21}$ based on the position of the Norwegian Continental Shelf front (NCF), Arctic front (AF) and polar front (PF). (c) Location of ODP Sites 642 and 907, and the modern surface circulation with inflow of warm Atlantic water via the Norwegian Atlantic Current (NwAC) and outflow of cool, polar water via the East Greenland Current (EGC). (d) Map of the Northern Hemisphere modern annual sea surface temperatures (from the World Ocean Atlas 2005, ref. 52), showing all ocean drill sites mentioned in the text. E, Eirik Drift; G, Gloria Drift. Black box shows study area in the Nordic Seas (see a,b,c).

the interval. Acritarchs are also abundant and dominated by C.? invaginata and L. crista, the same taxa as in the Norwegian Sea. Together this suggests an open-ocean environment, with occasional influx from the outer shelf (Spiniferites spp.). This interval also records the highest concentrations of the entire studied interval, with dinoflagellate cyst concentrations of 9,073 $\pm 1,308$ cysts per g sediment, and acritarch concentrations of 6,199 \pm 958 acritarchs per g sediment. In general, the assemblage composition at ODP Hole 907A is comparable to ODP Hole 642B, but the more oceanic species $N$. labyrinthus is dominant and dinoflagellate cyst concentrations are lower. This is consistent with the more open-ocean setting of ODP Hole 907A compared with the outer shelf environment at the Vøring Plateau ODP Hole 642B. The co-occurrence throughout the interval of dinoflagellate cysts with a warm-water affinity such as Impagidinium aculeatum, Invertocysta lacrymosa, M. choanophorum, O. israelianum, O. tegillatum and O.? eirikianum and the cool-tolerant taxa S. elongatus (common to dominant) and I. pallidum (rare to common) indicates temperate conditions in the Iceland Sea and inflow of warm Atlantic water (see Supplementary Note 1).

After 4.5 Ma, the palynological record indicates an open-ocean environment, with cool-water conditions between 4.5 and $4.26 \mathrm{Ma}$ and followed by a long barren interval until $2.6 \mathrm{Ma}$ (with a few exceptions, see Supplementary Note 2), indicating harsh conditions for dinoflagellate cysts and acritarchs. The Pliocene marker species, including the warm-water species O.? eirikianum, and Protoperidiniods disappear between 4.5 and $4.4 \mathrm{Ma}$, but dinoflagellate cysts remain present until $4.26 \mathrm{Ma}$ (Fig. 2; Supplementary Data 2). Nevertheless, dinoflagellate cyst and acritarch concentrations decrease considerably after $4.5 \mathrm{Ma}$ leading to a total crash at $4.14 \mathrm{Ma}$, when the assemblage becomes taxonomically depleted. In contrast to the transition towards an assemblage dominated by cysts of $P$. reticulatum observed in ODP Hole 642B, the impoverished assemblage in ODP Hole 907A between 4.5 and $4.26 \mathrm{Ma}$ remains dominated by the oceanic species $N$. labyrinthus, and occasionally Impagidinium cf. pacificum and I. pallidum. This indicates an open-ocean environment, with little or no influence from the shelf, and cool-water conditions. Warm-water taxa (for example, O.? eirikianum) that were recorded previously at this site are almost entirely absent after $4.45 \mathrm{Ma}$. From 4.26 to $2.6 \mathrm{Ma}$, ODP Hole $907 \mathrm{~A}$ is characterized by a long interval of nearly barren palynological samples containing less than 10 cysts counted per sample and concentrations below 60 cysts per $\mathrm{g}$ sediment. The absence of cysts of $P$. reticulatum and thermophilic taxa, which respectively thrive and persist in the Norwegian Sea, indicates that warm Atlantic water did not influence the Iceland Sea.

Iceland Sea ODP Hole 907A alkenone sea surface temperatures. Our low-resolution sea surface temperature reconstruction for Iceland Sea ODP Hole 907A based on the alkenone unsaturation index $\left(U_{37}^{k^{\prime}}\right)$ indicates considerably higher annual sea surface temperatures in the early Pliocene compared with present (Fig. 3; Supplementary Table 1). At $4.5 \mathrm{Ma}$, a persistent cooling can be observed followed by a further cooling after $4 \mathrm{Ma}$, yet at all time remaining warmer than present.

\section{Discussion}

If the late Miocene to earliest Pliocene ( $>4.5 \mathrm{Ma}$ ) Nordic Seas circulation were the same as today, a clear contrast between the 


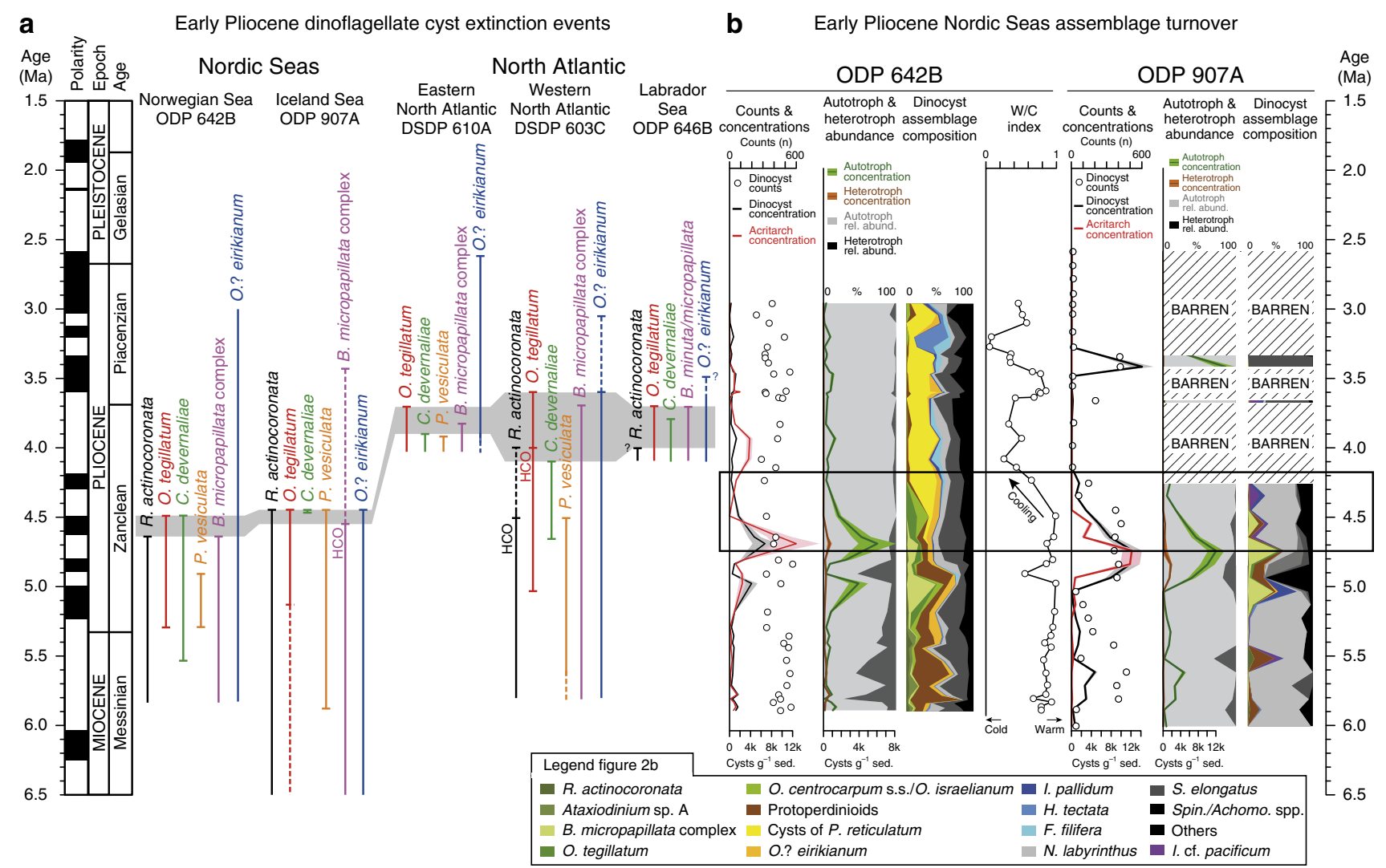

Figure 2 | Dinoflagellate cyst biostratigraphic and palaeoenvironmental reconstructions for the early Pliocene Nordic Seas. (a) Early Pliocene dinoflagellate cyst extinction events at ocean drill sites in the Nordic Seas and North Atlantic demonstrating the synchronous response of the dinoflagellate cyst assemblage around 4.5 Ma within the Nordic Seas, and the delayed extinctions in the North Atlantic. The grey-shaded area indicates the time interval wherein $R$. actinocoronata, $\mathrm{O}$. tegillatum, $\mathrm{C}$. devernaliae and B. micropapillata complex get extinct. $\mathrm{HCO}$, highest common occurrence. (b) Dinoflagellate cysts and acritarch concentrations and assemblage composition reflect a major assemblage turnover around 4.5 Ma (as indicated by the black rectangle) at ODP Hole 642B and ODP Hole 907A. The Warm/Cold (W/C) index at ODP Hole 642B reveals a cooling associated with the assemblage turnover. Shaded areas for concentration records indicate error. Barren intervals contain less than 10 counted dinoflagellate cysts. Inset box legend Fig. $2 b$ presents the colour coding used for the dinoflagellate cyst assemblage composition graphs. Spin./Achomo. spp., Spiniferites/Achomosphaera spp.

warm Atlantic-influenced Norwegian Sea and the cool Arcticinfluenced Iceland Sea should be visible in the palynological record. In contrast, our early Pliocene (5.0-4.5 Ma) dinoflagellate cyst records show that only a weak-to-absent zonal sea surface temperature gradient existed between the Norwegian and Iceland seas, and second, that the surface water evolution in both seas is coupled and influenced by Atlantic water. Notwithstanding some differences due to the different environment at both studied sites, the earliest Pliocene records from the Norwegian Sea and Iceland $\mathrm{Sea}^{23}$ are very comparable before $4.5 \mathrm{Ma}$ : at both sites the same early Pliocene markers and abundant taxa (Batiacasphaera, $N$. labyrinthus, $O$. tegillatum and Spiniferites) occur and palynomorph concentrations reach the highest values for the late Miocene to late Pliocene interval (Fig. 2). The dinoflagellate cyst assemblages indicate warm temperate conditions in the Norwegian Sea and temperate conditions in the Iceland Sea, implying that a strong, modern zonal surface temperature gradient was absent (Fig. 3). The presence of (sub)tropical dinoflagellate cysts (for example, $L$. machaerophorum, $M$. choanophorum and T. vancampoae) in both the Norwegian Sea and Iceland Sea indicate that warm Atlantic water influenced the entire Nordic Seas. Furthermore, ostracod ${ }^{5}$, mollusk $^{7,27}$ and dinoflagellate cyst ${ }^{28}$ assemblages as well as mollusk $\delta^{18} \mathrm{O}$ palaeotemperature reconstructions ${ }^{6}$ from the shallow marine Tjörnes Beds in northeastern Iceland indicate warm conditions at that time (Fig. 3). Also our low-resolution alkenone sea surface temperature record from the Iceland Sea indicates warm surface water conditions before $4.5 \mathrm{Ma}$ and a variability that is largely comparable to the Norwegian Sea W/C index (Fig. 3; Supplementary Note 3). This suggests a coupling of the temperature and surface water masses evolution in the Norwegian Sea and Iceland Sea between 5.0 and 4.5 Ma (Fig. 4).

The Norwegian Sea and Iceland Sea temperature evolution becomes uncoupled after $4.5 \mathrm{Ma}$ and the Atlantic water influence weakened in the Iceland Sea, which became gradually more influenced by cool, fresh water from the East Greenland Current. Around 4.5 Ma, the Norwegian Sea and Iceland Sea dinoflagellate cyst assemblage underwent a major turnover (Fig. 2; Supplementary Table 2), which we interpret as a cooling followed by the development towards the modern circulation in the Nordic Seas. In Norwegian Sea ODP Hole 642B, this turnover is expressed in a cluster of extinction events, a decrease in the W/C index and a shift from assemblages with an important heterotrophic component (Barssidinium, Brigantedinium, Selenopemphix, round brown cysts) to assemblages dominated by cysts of $P$. reticulatum (Fig. 2). The distribution of the cysts of $P$. reticulatum in recent sediments closely matches the Gulf Stream and North Atlantic Drift in the North Atlantic ${ }^{29}$ and the Norwegian Atlantic Current in the Nordic Seas ${ }^{30}$. In Pliocene records, the dominant presence of this species has been interpreted as evidence for the North Atlantic Current in the eastern North Atlantic ${ }^{31}$ and inflow of North Atlantic water into 


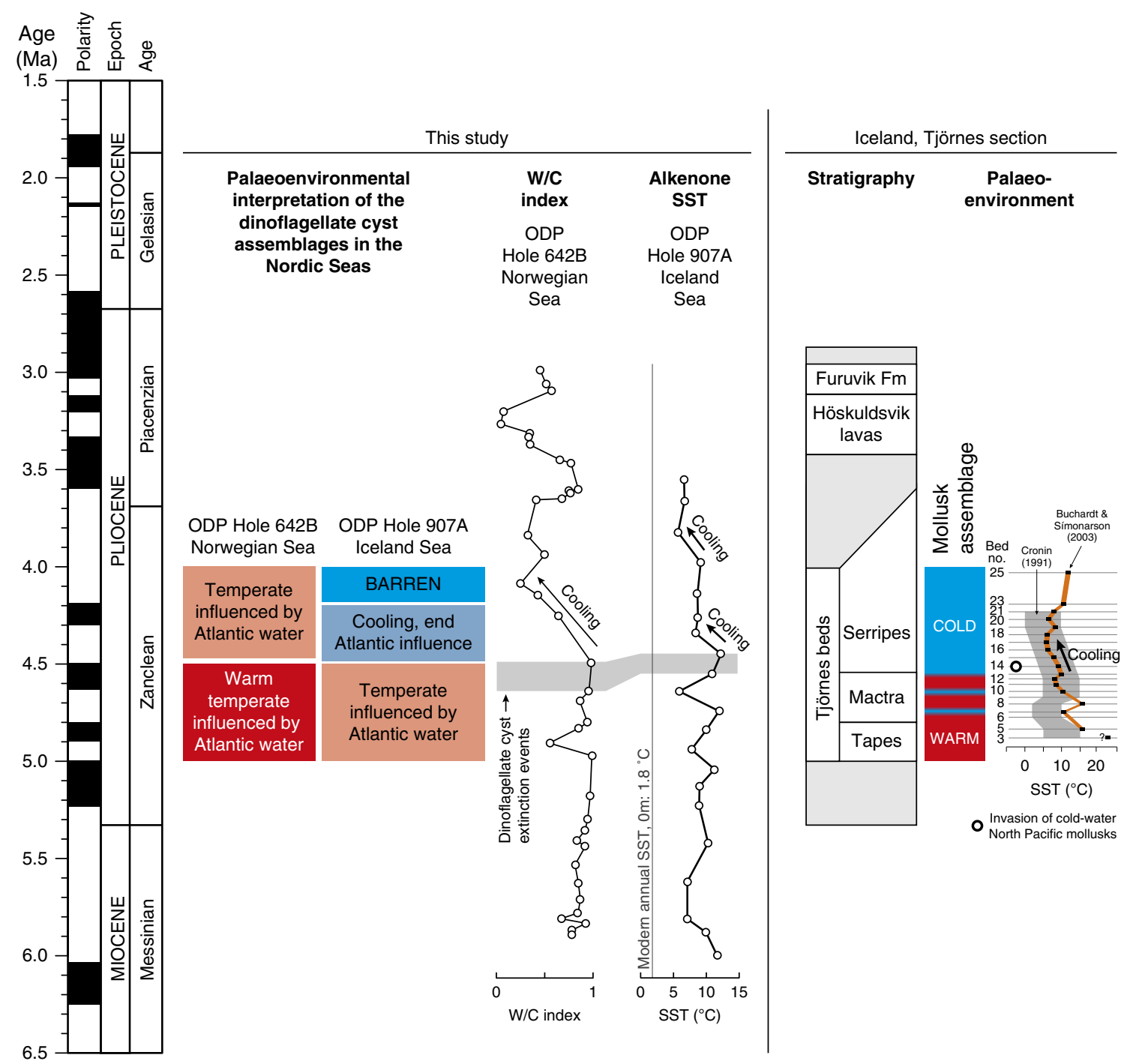

Figure 3 | Evidence for cooling in the Nordic Seas region around 4.5 Ma. The Nordic Seas dinoflagellate cyst assemblages, the Norwegian Sea ODP Hole 642B W/C index, the Iceland Sea ODP Hole 907A low-resolution alkenone sea surface temperature (SST), and the mollusk assemblages, marine ostracod palaeotempreature estimates ${ }^{5}$ (grey shading) and mollusk $\delta^{18} \mathrm{O}$ palaeotemperature estimates ${ }^{6}$ (orange curve) from shallow marine deposits in the Tjörnes section (NE Iceland) all show distinct cooling around 4.5 Ma. Tjörnes Beds stratigraphy and bed numbering (horizontal lines indicate approximate position of beds) are from the age model of ref. 8. Note that position and age of the beds are approximate, but beds $11-14$ belong to the $\mathrm{C} 3 \mathrm{n} .2 \mathrm{n}$ subchron (normal polarity, 4.631-4.493 Ma) and bed 25 is in the C2Ar subchron (reversed polarity, 4.187-3.596 Ma) ${ }^{8}$. Modern annual average sea surface temperatures from World Ocean Atlas $(2005)^{52}$.

the Nordic Seas ${ }^{25}$. Its appearance in Norwegian Sea ODP Hole $642 \mathrm{~B}$ after $4.5 \mathrm{Ma}$ onwards is consistent with the first establishment of a more modern-like Norwegian Atlantic Current. A reduction of warm-water species and increase of cooler-water species (for example, Habibacysta tectata and F. filifera) after $4.5 \mathrm{Ma}$ is reflected in a decreasing W/C index, demonstrating a significant early Pliocene cooling (Fig. 3). Nevertheless, (sub)tropical and thermophilic species such as O.? eirikianum, M. choanophorum and D. pseudocolligerum continue to be present, suggesting that warmer-than-present sea surface conditions persisted in the Norwegian Sea.

In contrast, cysts of $P$. reticulatum were never recorded in the Iceland Sea, and M. choanophorum and O.? eirikianum disappear at $4.5 \mathrm{Ma}$, indicating substantial cooling and waning of an Atlantic water influence there. In fact, the palynomorph assemblages and alkenone record in ODP Hole 907A provide evidence that a cool Arctic domain and proto-East Greenland Current were established after $4.5 \mathrm{Ma}$, when the early Pliocene productive interval is abruptly halted and followed by a long barren interval. At $4.5 \mathrm{Ma}$, the same dinoflagellate cyst species as in the Norwegian Sea go extinct, palynomorph concentrations and productivity decrease and heterotrophic species disappear (Fig. 2). This turnover and the following barren interval have been attributed to decreasing sea surface temperatures and salinity changes due to arrival of cool, fresh waters of a proto-East Greenland Current at the site $e^{23}$. A cooling of the Iceland Sea after 4.5 Ma is evident in our low-resolution ODP Hole 907A alkenone sea surface temperature record, as well as in ostracod and mollusk-isotope palaeotemperature reconstructions from the Tjörnes Beds ${ }^{5,6}$ (Fig. 3). The further cooling of sea surface temperatures in the Iceland Sea and expansion of a sea-ice cover from the Central Arctic Ocean to the marginal eastern Arctic ${ }^{32}$ after 4.0 Ma provide evidence for increasingly cool and fresh water transport via the East Greenland Current. The contemporaneous onset of biogenic opal accumulation at ODP Site 646 in the Labrador Sea was similarly linked to sea-ice-edge 
a

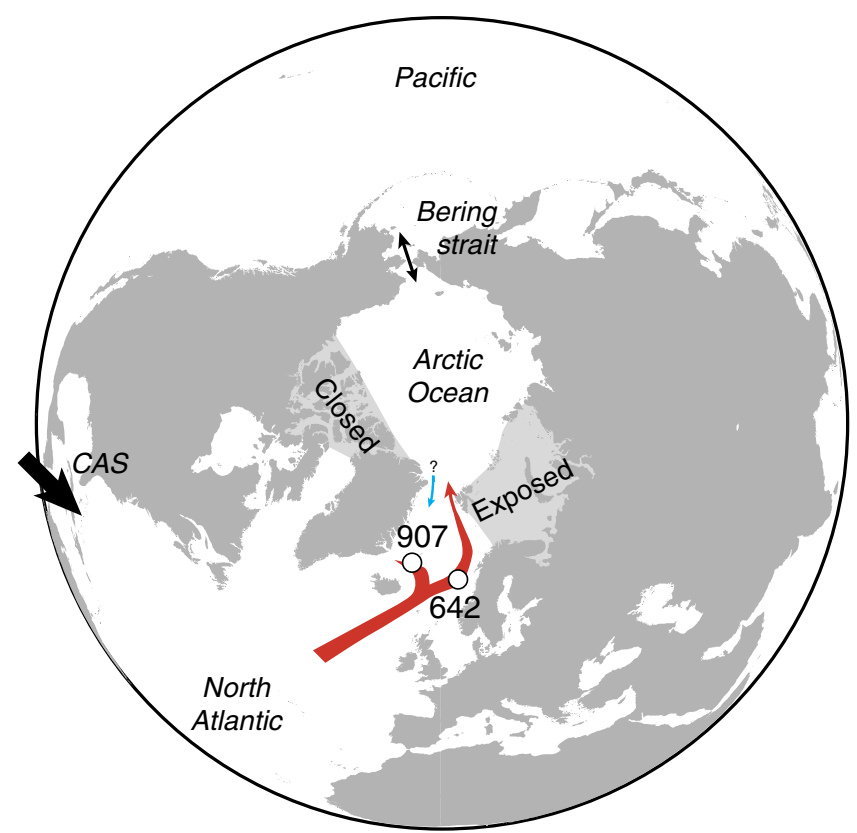

b

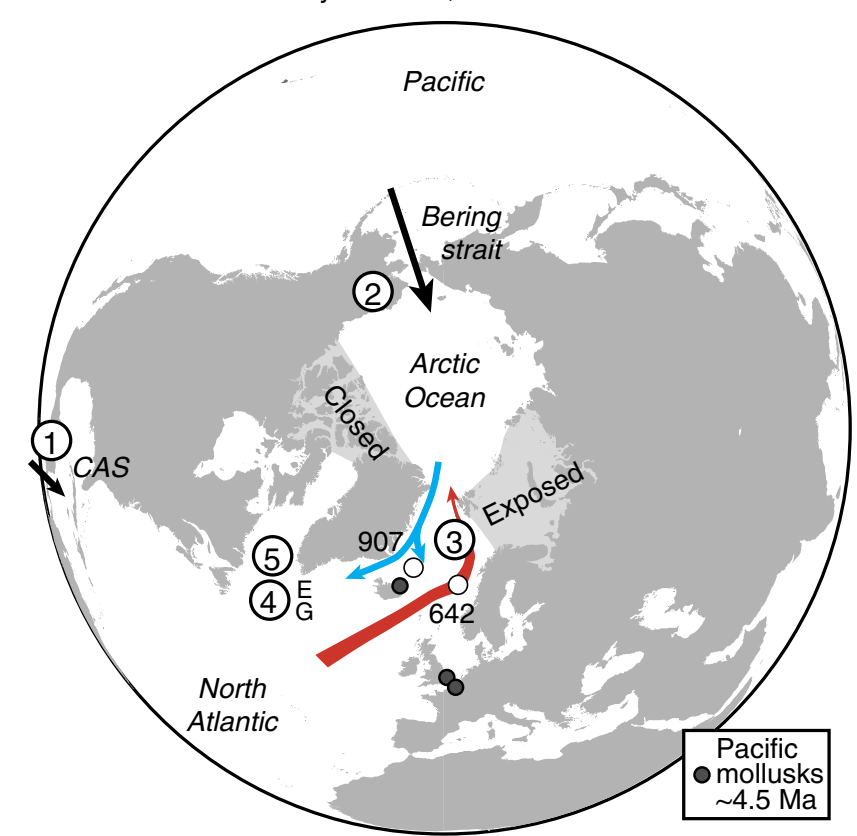

Figure 4 | Latest Miocene and early Pliocene Nordic Seas surface circulation in relation to Pacific-Arctic-Atlantic gateway evolution. (a) Before 4.5 Ma, the Nordic Seas were mainly influenced by warm North Atlantic waters. (b) After 4.5 Ma, shoaling at Central American Seaway and reduction in Pacific-Atlantic exchange (1), and opening and northward flow through the Bering Strait (2) led to development of a modern-like Nordic Seas circulation with an East Greenland Current and Norwegian Atlantic Current (3), changes in deep-water circulation at the Eirik (E) and Gloria (G) Drift deposits (4) and cooling in the Labrador Sea (5).

diatom production and significant surface water cooling due to export of polar water ${ }^{17}$. But probably the best evidence for Pacific cool-water inflow into the Nordic Seas around $4.5 \mathrm{Ma}$ is the first occurrence of cool-water Pacific mollusks (for example, Mya arenaria Linnaeus, Macoma obliqua Sowerby) in sediments of the Tjörnes section in Iceland and even in the North Sea Basin (see Supplementary Table 3).

The cooling and freshening of the East Greenland Current and development of an Arctic domain in the Nordic Seas can be directly tied to the inflow of fresher Pacific water via the Bering Strait (Fig. 4). First, for Pacific mollusks to have arrived in the North Atlantic realm around 4.5 Ma, the Arctic Ocean must have been (seasonally) sea-ice free and Nordic Seas surface water temperatures must have decreased to subarctic values. Before $4 \mathrm{Ma}$, the seas along the Arctic Ocean margins were perennially ice-free ${ }^{32}$, and from $4.5 \mathrm{Ma}$ Nordic Seas surface water temperatures dropped considerably. This is evidenced in the palynomorph assemblage turnover at both the studied sites, the decrease in the W/C index at ODP Hole 642B, the cooling recorded in the Iceland Sea alkenone record, palaeotemperature reconstructions at the Tjörnes Beds $s^{5,6}$ and invasion of cool-water mollusks (Fig. 3). Second, and maybe most importantly, for Pacific mollusks to have arrived in the Tjörnes section around 4.5 Ma, crucially the Pacific-Arctic-Atlantic gateways must have been open. One of the hypotheses explaining the strongly asymmetric trans-Arctic interchange of marine invertebratesPacific invaders outnumber those from the Arctic-Atlantic by a ratio of $8: 1$-is a dominantly northward flow of Pacific water through an open Bering Strait into the Arctic and eventually Nordic Seas ${ }^{7,33}$. The condition of open gateways was established by the late Miocene, when the Fram Strait was open for deepwater exchange ${ }^{26}$ and also the Bering Strait was open by 5.5-5.4 Ma (refs 34,35), possibly as early as 7.4-7.3 Ma (ref. 36). The Bering Strait and Fram Strait were then the only high- latitude connections between the Atlantic and Pacific, since the Canadian Arctic Archipelago was closed and Barents Sea subaerially exposed ${ }^{37}$. Our data are consistent with northward flow of cool, fresh Pacific water through the Bering Strait continuing via the Arctic into the Nordic Seas along the East Greenland Current pathway. In the tropics, deep-water exchange across the Central American Seaway was likely halted by the late Miocene ${ }^{12-14}$, but shallow exchange became gradually more restricted between 4.8-4.2 Ma (refs 15,16). Such exchange persisted until $\sim 2.5 \mathrm{Ma}$ (ref. 12), possibly via transient channels west of the Panama Canal Basin ${ }^{14}$, allowing an active North Atlantic meridional overturning circulation. Early Pliocene Central American Seaway shoaling has been linked mainly to changes in the North Atlantic surface and deep circulation ${ }^{12,15-17}$, but it may also have led to Pacific-to-Atlantic flow through the Bering Strait ${ }^{9}$ via an increased North Pacific sea level relative to the North Atlantic ${ }^{18,19}$. Today, water flow through the open Bering Strait is mainly from the Pacific to the Arctic and is sustained by a sea-level difference and salinity contrast between both basins ${ }^{38}$. Therefore, supported by a contemporaneous timing of the changes at the Pacific-Atlantic gateways and the development towards a proto-East Greenland Current and Norwegian Atlantic Current after $4.5 \mathrm{Ma}$, there thus is a link between northward flow through the Bering Strait-itself probably due to Central American Seaway shoaling-and the development of the modern Nordic Seas circulation. It is important to note that the flow through the Bering Strait may have had a more direct impact on Nordic Seas circulation, deep-water formation and global climate than previously believed.

The dinoflagellate cysts that disappear from the Nordic Seas around $4.5 \mathrm{Ma}$ only go extinct in the North Atlantic after $\sim 4 \mathrm{Ma}$, indicating a 500-kyr delay (Fig. 2). The North Atlantic extinctions are coeval with a decreasing global sea surface temperature ${ }^{2}$, implying that the development of the zonal sea surface 
temperature gradient in the Nordic Seas around 4.5 Ma predates the early Pliocene global cooling. Therefore, the fundamental oceanographic change in the Nordic Seas was not caused by global climate evolution ${ }^{2}$, but is more likely attributable to changes in Pacific-Atlantic oceanic gateway configurations.

It is interesting that North Atlantic surface waters cooled from $4 \mathrm{Ma}$ onwards, whereas changes in Nordic Seas circulation and North Atlantic deep-water circulation are apparent 500-kyrs earlier (Figs 2 and 3). In the early Pliocene northeast Atlantic, a major unconformity was related to changed deep-ocean circulation $^{39}$. At the Eirik Drift, an excellent recorder of deep-water currents originating from overflows from Nordic Sea Deep Water formation regions, an erosional unconformity and a highamplitude reflector have been identified at $4.5 \mathrm{Ma}$ (ref. 40). This reflector indicates the influence of a strong deep current likely due to circulation changes and enhanced deep-water formation in the Nordic Seas. Indeed, the Denmark Strait overflow increased around that time ${ }^{17}$, possibly aided by regional subsidence, with sustained production of Northern Component Water thereafter ${ }^{41}$. On the Gloria Drift, sediment accumulation started at $4.5 \mathrm{Ma}$, and several North Atlantic sediment drifts reveal overall highest apparent sedimentation rates in the early Pliocene ${ }^{42}$, indicating a major change towards a bottomcurrent-dominated regime. The early Pliocene change in North Atlantic deep-water circulation is simultaneous with development of the modern Nordic Seas circulation at 4.5 Ma underlining the importance of Pacific water flow into the Atlantic via the Bering Strait on the thermohaline circulation.

In summary, a modern Nordic Seas circulation with a strong east-west surface water temperature gradient developed since $4.5 \mathrm{Ma}$ as a result of contemporaneous gateway reconfigurations in the Central American Seaway and Bering Strait. The flow of Pacific waters through the Bering Strait had a direct effect on Nordic Seas circulation, but may ultimately be caused by impeded flow through the Central American Seaway and consequent buildup of a Pacific-Atlantic salinity and sea-level gradient. The Pacific-to-Atlantic flow via the Bering Strait cooled and freshened the East Greenland Current, in fact establishing an Arctic domain in the Nordic Seas and isolating Greenland from warm Atlantic waters of the Norwegian Atlantic Current. This was an important precondition for more widespread glaciation on Greenland that remained restricted in the early Pliocene ${ }^{43}$, but gradually increased following regional circum-Arctic uplift around 4.0 Ma (ref. 26) and late Pliocene decreasing atmospheric carbon dioxide concentrations ${ }^{4}$. Establishment of a modern Nordic Seas circulation pattern also intensified North Atlantic Deep Water formation, making the region a fundamental part of the Atlantic meridional overturning circulation and a key region in global climate variability since the early Pliocene.

\section{Methods}

Marine palynology. We investigated the dinoflagellate cysts and acritarchs of 40 samples across the time interval between 5.8 and $3.0 \mathrm{Ma}(94.95-64.54 \mathrm{mbs})$ at Vøring Plateau ODP Hole $642 \mathrm{~B}\left(67^{\circ} 13.5^{\prime} \mathrm{N}, 2^{\circ} 55.7^{\prime} \mathrm{E}\right.$; water depth $1,268 \mathrm{~m}$; Fig. 1). The samples were prepared using a standard palynological maceration procedure, which included weighing dried sediment, adding one Lycopodium clavatum tablet (batch \#483216), digestion cycles in cold $\mathrm{HF}$ and cold $\mathrm{HCl}$, no oxidation, occasional mild ultrasonic treatment and sieving at $10 \mu \mathrm{m}$ before mounting the residue on microscope slides. Slides were then counted using a light microscope at $\times 400$ magnification along non-overlapping traverses until at least 250 specimens were counted, or until the slide was completely scanned.

The total error on the palynomorph concentration is calculated following the method outlined in ref. 44: total error $e=\sqrt{e_{1}^{2}+e_{2}^{2}+e_{2}^{3}}$ with $e_{1}=$ error on number of spores in L. clavatum marker tablets, $\mathrm{e}_{2}=$ error on number of dinoflagellate cysts counted and $\mathrm{e}_{3}=$ error on number of $L$. clavatum markers counted.

The Warm/Cold (W/C) index is calculated based on the dinoflagellate cyst occurrences according to the formula $\mathrm{W} / \mathrm{C}=n \mathrm{~W} /(n \mathrm{~W}+n \mathrm{C})$, with $n=$ number of specimens counted, $\mathrm{W}=$ warm-water species, $\mathrm{C}=$ cold-water species. The ecological preference of each species included in the index was considered in relation to their distribution in the modern oceans ${ }^{45,46}$ and in Pliocene deposits ${ }^{4-50}$. This resulted in using the following species as warm-water species: Achomosphaera andalousiensis subsp. suttonensis, D. pseudocolligerum, Hystrichokolpoma rigaudiae, I. aculeatum, I. paradoxum, I. patulum, I. solidum, I. lacrymosa, I. tabulata, L. machaerophorum, M. choanophorum, O.? eirikianum, O. centrocarpum s.s./O. israelianum, O. tegillatum, S. mirabilis/hyperacanthus, Tectatodinium pellitum and Tubercoludinium vancampoae. The cool-water species were: Bitectatodinium tepikiense, F. filifera, H. tectata, I. pallidum and S. elongatus. A reliable W/C index could not be calculated for ODP Hole 907A over the entire studied interval, because the total dinoflagellate cyst count was often lower than 100 cysts per sample in the Pliocene and/or the sum of cold and warm specimens was lower than 10 .

A full authorial citation of the dinoflagellate cyst species mentioned in the text and figures is given in the Supplementary Note 4 .

All raw data from ODP Hole 642B is available at doi: $10.1594 /$ PANGAEA.846838; data from ODP Hole $907 \mathrm{~A}\left(69^{\circ} 15.0^{\prime} \mathrm{N}, 12^{\circ} 41.9^{\prime} \mathrm{W}\right.$; water depth 2,036 m; Fig. 1) is available at doi:10.1594/PANGAEA.807163. Summarized data is presented in Supplementary Data 1 and 2.

Biomarker analyses. For alkenone analyses, freeze-dried and homogenized sediments ( 2 to $4 \mathrm{~g}$ ) were extracted with an Accelerated Solvent Extractor (DIONEX, ASE $200 ; 100^{\circ} \mathrm{C}, 1,000 \mathrm{psi}, 5 \mathrm{~min}$ ) using dichloromethane and methanol $(99: 1, \mathrm{v} / \mathrm{v})$ as solvent. The separation of compounds was carried out by open-column chromatography $\left(\mathrm{SiO}_{2}\right)$ using $n$-hexane and dichloromethane $(1: 1, \mathrm{v} / \mathrm{v})$, and dichloromethane. The composition of alkenones was analysed with an Agilent gas chromatograph $(7890$, column $60 \mathrm{~m} \times 0.32 \mathrm{~mm}$; film thickness $0.25 \mu \mathrm{m}$; liquid phase: DB1-MS) using a temperature program as follows: $60^{\circ} \mathrm{C}$ $(3 \mathrm{~min}), 150^{\circ} \mathrm{C}\left(\right.$ rate: $\left.20^{\circ} \mathrm{C} \mathrm{min}{ }^{-1}\right), 320^{\circ} \mathrm{C}\left(\right.$ rate: $\left.6^{\circ} \mathrm{C} \mathrm{min}^{-1}\right)$ and $320^{\circ} \mathrm{C}(40 \mathrm{~min}$ isothermal). For splitless injection, a cold injection system was used $\left(60{ }^{\circ} \mathrm{C}(6 \mathrm{~s})\right.$, $340^{\circ} \mathrm{C}$ (rate: $\left.12^{\circ} \mathrm{C} \mathrm{s}^{-1}\right), 340^{\circ} \mathrm{C}(1 \mathrm{~min}$, isothermal $\left.)\right)$. Helium was used as carrier gas $\left(1.2 \mathrm{ml} \mathrm{min}^{-1}\right)$. Individual alkenone $\left(C_{37: 3}, C_{37: 2}\right)$ identification is based on retention time and the comparison with an external standard.

The alkenone unsaturation index $\left(U_{37}^{k}\right)$ as proxy for mean annual sea surface temperature $\left({ }^{\circ} \mathrm{C}\right)$ was calculated following ref. 51 , based on a global core-top calibration $\left(60^{\circ} \mathrm{N}-60^{\circ} \mathrm{S}\right): U_{37}^{k^{\prime}}=0.033 \times \mathrm{T}\left({ }^{\circ} \mathrm{C}\right)+0.044$. The s.e. of the calibration is reported as $\pm 0.050 U_{37}^{k}$ units or $\pm 1.5^{\circ} \mathrm{C}$. The instrument stability was continuously controlled by re-runs of an external alkenone standard (extracted from Emiliania huxleyi cultures with known growth temperature) during the analytical sequences. The range of the total analytical error calculated by replicate analyses is less than $0.4^{\circ} \mathrm{C}$. The data are presented in Supplementary Table 1 and are available from doi:10.1594/PANGAEA.848671.

Age models. Tie points used to construct the age model of ODP Holes 642B, 646B, 907A and Deep Sea Drilling Project (DSDP) Holes 603C, 610A are presented in the Supplementary Tables $4-8$.

\section{References}

1. Fedorov, A. V. et al. The Pliocene paradox (mechanisms for a permanent El Niño). Science 312, 1485-1489 (2006).

2. Fedorov, A. V. et al. Patterns and mechanisms of early Pliocene warmth. Nature 496, 43-49 (2013).

3. Brierley, C. et al. Greatly expanded tropical warm pool and weakened Hadley circulation in the Early Pliocene. Science 323, 1714-1718 (2009).

4. Seki, O. et al. Alkenone and boron-based Pliocene $\mathrm{pCO}_{2}$ records. Earth Planet Sci. Lett. 292, 201-211 (2010).

5. Cronin, T. M. Late Neogene marine Ostracoda from Tjörnes, Iceland. J. Paleontol. 65, 767-794 (1991).

6. Buchardt, B. \& Símonarson, L. Isotope palaeotemperatures from the Tjörnes beds in Iceland: evidence of Pliocene cooling. Palaeogeogr. Palaeoclimatol. Palaeoecol. 189, 71-95 (2003).

7. Durham, J. W. \& MacNeil, F. S. in The Bering Land Bridge (ed. Hopkins, D. M.) 326-349 (Stanford Univ. Press, 1967).

8. Verhoeven, K., Louwye, S., Eiríksson, J. \& De Schepper, S. A new age model for the Pliocene-Pleistocene Tjörnes section on Iceland: its implication for the timing of North Atlantic-Pacific palaeoceanographic pathways. Palaeogeogr. Palaeoclimatol. Palaeoecol. 309, 33-52 (2011).

9. Marincovich, L. Central American paleogeography controlled Pliocene Arctic Ocean molluscan migrations. Geology 28, 551-554 (2000).

10. $\mathrm{Hu}, \mathrm{A}$. et al. Influence of Bering Strait flow and North Atlantic circulation on glacial sea-level changes. Nat. Geosci. 3, 118-121 (2010).

11. Marincovich, L. \& Gladenkov, A. Y. Evidence for an early opening of the Bering Strait. Nature 397, 149-151 (1999).

12. Osborne, A. H. et al. The seawater neodymium and lead isotope record of the final stages of Central American Seaway closure. Paleoceanography 29, 715-729 (2014).

13. Sepulchre, P. et al. Consequences of shoaling of the Central American Seaway determined from modeling Nd isotopes. Paleoceanography 29, 176-189 (2014). 
14. Montes, C. et al. Middle Miocene closure of the Central American Seaway. Science 348, 226-229 (2015).

15. Haug, G. H. \& Tiedemann, R. Effect of the formation of the Isthmus of Panama on Atlantic Ocean thermohaline circulation. Nature 393, 673-676 (1998).

16. Steph, S. et al. Early Pliocene increase in thermohaline overturning: a precondition for the development of the modern equatorial Pacific cold tongue. Paleoceanography 25, PA2202 (2010).

17. Bohrmann, G., Henrich, R. \& Thiede, J. in Geological History of the Polar Oceans: Arctic versus Antarctic (eds Bleil, U. \& Thiede, J.) 647-675 (Kluwer Academic Publishers, 1990).

18. Maier-Reimer, E., Mikolajewicz, U. \& Crowley, T. Ocean general circulation model sensitivity experiment with an open Central American Isthmus. Paleoceanography 5, 349-366 (1990).

19. Sarnthein, M. et al. Mid-Pliocene shifts in ocean overturning circulation and the onset of Quaternary-style climates. Clim. Past 5, 269-283 (2009).

20. Clark, P., Pisias, N., Stocker, T. \& Weaver, A. The role of the thermohaline circulation in abrupt climate change. Nature 415, 863-869 (2002).

21. Swift, J. H. in The Nordic Seas (ed. Hurdle, B. G.) 129-153 (Springer, 1986)

22. Hansen, B. \& Østerhus, S. North Atlantic-Nordic Seas exchanges. Progr. Oceanogr. 45, 109-208 (2000).

23. Schreck, M., Meheust, M., Stein, R. \& Matthiessen, J. Response of marine palynomorphs to Neogene climate cooling in the Iceland Sea (ODP Hole 907A). Mar. Micropaleontol. 101, 49-67 (2013).

24. Dale, B. \& Dale, A. in Quaternary environmental micropaleontology (ed. Haslett, S. K.) 207-239 (Arnold, 2002).

25. Knies, J., Matthiessen, J., Vogt, C. \& Stein, R. Evidence of 'Mid-Pliocene (c. $3 \mathrm{Ma}$ ) global warmth' in the eastern Arctic Ocean and implications for the Svalbard/Barents Sea ice sheet during the late Pliocene and early Pleistocene ( 3 - 1.7 Ma). Boreas 31, 82-93 (2002).

26. Knies, J. et al. Effect of early Pliocene uplift on late Pliocene cooling in the Arctic-Atlantic gateway. Earth Planet. Sci. Lett. 387, 132-144 (2014).

27. Einarsson, T., Hopkins, D. M. \& Doell, R. M. in The Bering Land Bridge (ed. Hopkins, D. M.) 312-325 (Stanford Univ. Press, 1967).

28. Verhoeven, K. \& Louwye, S. Palaeoenvironmental reconstruction and biostratigraphy with marine palynomorphs of the Plio-Pleistocene in Tjörnes, Northern Iceland. Palaeogeogr. Palaeoclimatol. Palaeoecol. 376, 224-243 (2013)

29. Rochon, A., de Vernal, A., Turon, J.-L., Matthiessen, J. \& Head, M. J. Distribution of recent dinoflagellate cysts in surface sediments from the North Atlantic Ocean and adjacent seas in relation to sea-surface parameters. AASP Contrib. Ser. 35, 147 (1999).

30. Matthiessen, J. Distribution patterns of dinoflagellate cysts and other organicwalled microfossils in recent Norwegian-Greenland Sea sediments. Mar. Micropaleontol. 24, 307-334 (1995).

31. De Schepper, S. et al. Northern Hemisphere glaciation during the globally warm early late Pliocene. PLoS ONE 12, e81508 (2013).

32. Knies, J. et al. The emergence of modern sea ice cover in the Arctic Ocean. Nat. Commun. 5, 1-7 (2014).

33. Vermeij, G. J. Anatomy of an invasion: the trans-Arctic interchange. Paleobiology 281-307 (1991).

34. Gladenkov, A. Y., Oleinik, A., Marincovich, L. \& Barinov, K. B. A refined age for the earliest opening of Bering Strait. Palaeogeogr. Palaeoclimatol. Palaeoecol. 183, 321-328 (2002).

35. Gladenkov, A. Y. The Cenozoic diatom zonation and its significance for stratigraphic correlations in the North Pacific. Paleontol. J. 40, S571-S583 (2006).

36. Marincovich, L. \& Gladenkov, A. Y. New evidence for the age of Bering Strait. Quat. Sci. Rev. 20, 329-335 (2001).

37. Matthiessen, J., Knies, J., Vogt, C. \& Stein, R. Pliocene palaeoceanography of the Arctic Ocean and subarctic seas. Philos. Trans. A Math. Phys. Eng. Sci. 367, 21-48 (2009).

38. Aagaard, K. et al. Some controls on flow and salinity in Bering Strait. Geophys. Res. Lett. 33, L19602 (2006).

39. Stoker, M. et al. in Petroleum Geology: North West Europe and Global Perspectives: Proceedings of the 6th Petroleum Geology Conference (eds Doré, A. G. and Vining, B. A.) 1057-1076 (Geological Society, 2005).

40. Müller-Michaelis, A., Uenzelmann-Neben, G. \& Stein, R. A revised Early Miocene age for the instigation of the Eirik Drift, offshore southern Greenland: evidence from high-resolution seismic reflection data. Mar. Geol. 340, 1-15 (2013)
41. Poore, H. R., White, N. \& Jones, S. A Neogene chronology of Iceland plume activity from V-shaped ridges. Earth Planet. Sci. Lett. 283, 1-13 (2009).

42. Wold, C. N. Cenozoic sediment accumulation on drifts in the northern North Atlantic. Paleoceanography 9, 917-941 (1994)

43. De Schepper, S., Gibbard, P. L., Salzmann, U. \& Ehlers, J. A global synthesis of the marine and terrestrial evidence for glaciation during the Pliocene epoch. Earth Sci. Rev. 135, 83-102 (2014).

44. Stockmarr, J. Tablets with spores used in absolute pollen analysis. Pollen et Spores 13, 615-621 (1971)

45. Marret, F. \& Zonneveld, K. A. F. Atlas of modern organic-walled dinoflagellate cyst distribution. Rev. Palaebot. Palynol. 125, 1-200 (2003).

46. Zonneveld, K. A. F. et al. Atlas of modern dinoflagellate cyst distribution based on 2405 datapoints. Rev. Palaebot. Palynol. 191, 1-197 (2013).

47. De Schepper, S., Fischer, E., Groeneveld, J., Head, M. J. \& Matthiessen, J. Deciphering the palaeoecology of Late Pliocene and Early Pleistocene dinoflagellate cysts. Palaeogeogr. Palaeoclimatol. Palaeoecol. 309, 17-32 (2011).

48. Head, M. J. Thermophilic dinoflagellate assemblages from the mid Pliocene of eastern England. J. Paleontol. 71, 165-193 (1997).

49. Head, M. J. Late Cenozoic dinoflagellates from the Royal Society Borehole at Ludham, Norfolk, Eastern England. J. Paleontol. 70, 543-570 (1996).

50. Head, M. J. \& Westphal, H. Palynology and paleoenvironments of a Pliocene carbonate platform: The Clino core, Bahamas. J. Paleontol. 73, 1-25 (1999).

51. Müller, P. J., Kirst, G., Ruhland, G., von Storch, I. \& Rosell-Melé, A. Calibration of the alkenone paleotemperature index $U_{37}^{k}$ based on core-tops from the eastern South Atlantic and the global ocean $\left(60^{\circ} \mathrm{N}-60^{\circ} \mathrm{S}\right)$. Geochim. Cosmochem. Acta 62, 1757-1772 (1998).

52. Locarnini, R. A., Mishonov, A. V., Antonov, J. I., Boyer, T. P. \& Garcia, H. E in NOAA Atlas NESDIS 61. (ed. Levitus, S. S.) 182 (US Gov. Printing Office, 2006).

\section{Acknowledgements}

S.D.S. received funding from the Norwegian Research Council (project 229819) and M.S. from the Korea Polar Research Institute's Basic Research Project (PE15062) and a National Research Foundation of Korea Grant (2015M1A5A1037243). J.M. acknowledges funding from the Deutsche Forschungsgemeinschaft (project MA3913/2). This research used samples provided by the Integrated Ocean Drilling Program that were collected on behalf of B. Risebrobakken for the ESM (Earth System Modelling, funded by Statoil AS) and OCCP (Norwegian Research Council project 221712) projects. We thank the financial aid of Statoil AS (via the Utsira Project) for the laboratory costs. M. Jones of Palynological Laboratory Services Ltd (Holyhead, UK) performed the palynological preparations.

\section{Author contributions}

S.D.S. and G.M. designed the project. S.D.S., K.M.B., G.M., M.S. and J.M. generated and interpreted the palynological data. K.F. generated and analysed the alkenone data. S.D.S and M.S. wrote the manuscript, with contributions from K.M.B., J.M., K.F. and G.M.

\section{Additional information}

Supplementary Information accompanies this paper at http://www.nature.com/ naturecommunications

Competing financial interests: The authors declare no competing financial interests.

Reprints and permission information is available online at http://npg.nature.com/ reprintsandpermissions/

How to cite this article: De Schepper, S. et al. Early Pliocene onset of modern Nordic Seas circulation related to ocean gateway changes. Nat. Commun. 6:8659 doi: $10.1038 /$ ncomms 9659 (2015)

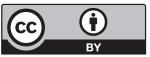

This work is licensed under a Creative Commons Attribution 4.0 International License. The images or other third party material in this article are included in the article's Creative Commons license, unless indicated otherwise in the credit line; if the material is not included under the Creative Commons license, users will need to obtain permission from the license holder to reproduce the material. To view a copy of this license, visit http://creativecommons.org/licenses/by/4.0/ 